\title{
The spiritual and the sacred: prospects for convergence between religious and non-religious outlooks ${ }^{1}$
}

\author{
JOHN COTTINGHAM
}

Two roads diverged in a yellow wood

And sorry I could not travel both

And be one traveller, long I stood

And looked down one as far as I could ...

Then took the other ...

Robert Frost ${ }^{2}$

\section{Divergence, convergence and objectivity}

People take different roads through life, not just in publicly visible ways, such as in their choice of occupations or partners, but also in respect of what might be called the interior tone of their lives. So two people with outwardly similar levels of achievement, health, and material goods may lead very different lives, the one seeing his or her existence as full of meaning and value, the other plagued by a sense of futility and purposelessness. Indeed, one and the same individual, as she or he goes through life, may switch from one state to the other, as reported by the protagonist at the start of Dante's La Divina Comedia: 'Half-way along the road that is our life/ I found myself inside a murky wood/ where the straight path ahead was all confused.'3

If the road ahead was always clear, with no existential crises of the kind Dante describes, and no crucial decision points such as Robert Frost refers to, the life in question would not be a recognizably human life - or at least it would be a very untypical one. Unlike the other animals, whose lives follow a set pattern determined by environmental conditions and their inbuilt drives and goals, each of us to a great extent maps out his or her own distinctive pathway, as we struggle to see the right way forward. Hence, while the life of any given cow or horse will not significantly diverge from that of any other in similar circumstances, the life of a human being, however much it may have in common with that of a similarly placed neighbour, always has its own unique trajectory.

We would not want it to be otherwise The varied and diverging forms of human activity, and the hard choices each of us faces about which path to follow, are a sign of humanity's greatness. ${ }^{4}$ Even though our freedom is not always comfortable, and its attendant dilemmas and doubts and mistakes can cause anguish, few of us would relish an existence in which all the available roads were made to converge into just one approved route.

Nevertheless, though divergence may in certain respects be something to be celebrated, there are other respects in which its opposite, convergence, is to be welcomed. In the domain of scientific inquiry, for example, it seems evident that a plethora of competing

1 This is a draft of a paper the definitive version of which appears in Richard Norman and Tony Carroll (eds), Religion and Atheism: Beyond the Divide (London: Routledge, 2017), Ch. 11, pp. 130-40.

2 Robert Frost, 'The Road Not Taken', from Mountain Interval (New York: Holt, 1920).

${ }^{3} \mathrm{Nel}$ mezzo del camin di nostra vita/mi ritrovai per una selva oscura/che la diritta via era smarrita. Dante Alighieri, La Divina Comedia: Inferno [c. 1310], Canto 1, opening lines, transl. JC.

${ }^{4}$ Compare René Descartes, Meditations [Meditationes in prima philosophia, 1641]: our will or freedom of choice is the one human faculty that is perfect of its kind, so that it is 'above all in virtue of the will that I understand myself to bear in some way the image and likeness of God'; Fourth Meditation, transl. J.C. (Descartes goes on to point out, however, that this quasi-divine power of free choice can nevertheless be a source of error and sin, when we exercise it in the wrong direction.) 
explanations for a given phenomenon is a sign that something is amiss. To be sure, different teams of scientists may pursue different hunches and different lines of inquiry, but the expectation is that ultimately our scientific theories will converge, or at least show a tendency to converge, as they get closer to the truth. As Bernard Williams once observed, in science 'there should ideally be convergence on an answer, where the best explanation of the convergence involves the idea that the answer represents how things are.' The very notion of objectivity in the sciences seems to presuppose that our theories and explanations should in principle be constrained by the way the world is, so that there will, or should ideally, be a convergence which is, as Williams went on to put it, 'guided ... by how things actually are'. ${ }^{5}$

In the domain of ethics, in contrast to that of scientific inquiry, Williams himself was very sceptical about the possibility of convergence: he saw no prospect of a 'convincing theory of knowledge for the convergence of reflective ethical thought on ethical reality in even a distant analogy to the scientific case'. ${ }^{6}$ His attitude here partly reflected the influence upon him of Nietzsche's deflationary view of the status of morality, that 'peculiar institution', as Williams called it, based on the (supposedly dubious) idea of binding and inescapable obligations. ${ }^{7}$ The current philosophical consensus however, has emerged as very much more sympathetic to the idea of objective and authoritative moral requirements than was common among Williams's generation; and it is probably fair to say that the majority of moral philosophers working today hold that there are objectively right answers to ethical and moral questions. Such answers may of course be very difficult to establish (requiring complex investigation and careful debate), and there may also be hard cases where we are forced to choose between competing goods, but in principle, so runs the prevailing contemporary view, genuine objective ethical truth about what is good and right is, as it were, already there waiting to be investigated, just as scientific truth is. And this gives grounds for thinking that, although it may take a long time to achieve, we may in principle expect an ultimate convergence in ethical thought, just as in science.

In the case of religious thought, by contrast, things look very different. For here what is at stake is not just the acceptance of a theory in physics (for example about the nature of gravity) or in ethics (for example about the relation between justice and utility), but the adoption of an outlook concerning the ultimate significance of the entire universe and our place within it. Thus the theist, who holds that the meaning of each individual's existence lies in his or her relationship to a loving personal Creator, will presumably see the whole of reality in a completely different light from the Buddhist who maintains that the very idea of an individual self is an illusion, or from the contemporary scientific naturalist who holds that our existence is a pure accident generated by forces that manifest only 'blind, pitiless indifference'. ${ }^{8}$ The prospect for convergence between such radically distinct and incommensurable worldviews appears, to say the least, to be remote.

Yet the advocates of the various theistic or non-theistic outlooks just mentioned all typically maintain that their own respective worldviews are objectively correct, representing the true, the enlightened, answer as to the ultimate nature of reality. And to espouse an objectivist view of truth, as our earlier discussion has indicated, is to hold that differing views ought ultimately to converge. Hence, if one maintains that, for example, the Islamic, or the Christian, or the scientific-naturalist worldview is objectively correct, this seems to carry with it a presumption that ultimately, given enough time, everyone on the planet should come to

\footnotetext{
${ }^{5}$ Bernard Williams, Ethics and the Limits of Philosophy (London: Collins, 1985), Ch. 8, p. 136.

${ }^{6}$ Williams, Ethics and the Limits, p. 152.

7 Williams, Ethics and the Limits, Ch. 10.

${ }^{8}$ Richard Dawkins, Rivers Out of Eden (New York: Basic Books, 1995), p. 133.
} 
acknowledge the truth of the worldview in question. Certainly many religious believers have indeed displayed just such a confident expectation of eventual convergence - a notable example being the attitude of many Christians in the imperialistic climate of nineteenthcentury England, as seen in a verse from the once popular hymn 'From Greenland's Icy Mountains':

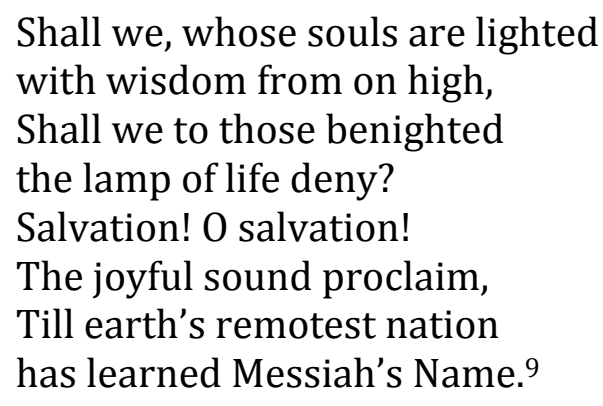

The attitude persists. In our own time we find militant fundamentalists of various creeds, secular as well as religious, who apparently envisage a world in which their own chosen form of orthodoxy will reign supreme over all the planet. But (no doubt as a result of many factors, including rapidly widening travel and communication) there has also arisen, in many quarters, a more reflective 'globalist' outlook that inclines towards tolerance for, and even welcoming of, diversity in religious belief, even on the part of those who are themselves devoutly committed to a particular creed or faith. Those attracted to this more tolerant stance may be prepared to put on indefinite hold, as it were, the theoretical requirement that competing worldviews should ultimately converge on the truth, constrained by the reality of 'how things actually are', and substitute instead the more modest hope of finding some convergence at the level not of doctrine and theory, but of practice and behaviour. For as Rudyard Kipling so eloquently observed over a century ago, it is at the practical level of human need, the universal longing for solace and comfort amid the inevitable pains of human life, that common ground is likely to be found, irrespective of differences of doctrine and ideology:

My brother kneels, so saith Kabir,

To stone and brass in heathen-wise, But in my brother's voice I hear My own unanswered agonies.

His God is as his fates assign;

His prayer is all the world's - and mine. ${ }^{10}$

\section{Spiritual praxis as common ground}

The Buddhist tradition speaks of Dukkha (suffering, anxiety, difficulty) as one of the fundamental features of human existence, and there is no doubt that many people turn to religion partly for urgent practical reasons, as a means of finding some way to cope with the suffering that is our human lot. Our modern technological age has tended to prioritize cost effective quick-fix solutions for our plight, such as tranquillizers and behaviour therapy, but

\footnotetext{
9 'From Greenland's Icy Mountains' (1819), by the Anglican parson Reginald Heber, who became Bishop of Calcutta in 1823.

${ }^{10}$ Rudyard Kipling, Kim [1901], Ch. XIV.
} 
the great religions, whether of the non-theistic variety (such as mainstream Buddhism) or the theistic kind (both polytheistic, as in Hinduism, and monotheistic, as in the Abrahamic faiths) have all evolved complex spiritual practices, including prayer, fasting, meditation, chanting, and various prescribed movements and rituals, part of whose purpose is evidently related to dealing with suffering; the goal is either eventually to escape from the world of suffering altogether, or else perhaps to reconfigure it within a framework of significance that alleviates it or helps us to bear it. In a more positive vein, such spiritual praxis also seems aimed at cultivating calmness of mind - what the Stoics called ataraxia (tranquillity) - together with an attitude of joyful openness and attentiveness to the good or the divine, or to reality as a whole.

These are complex notions whose diverse metaphysical implications would require much time and effort to explore; but when we look the varying religious traditions at the level of praxis rather than of theory, we do seem to find a considerable degree of convergence. If we observe a line of monks, clad in habits of uniform cut and colour, all with heads bowed in a posture of attentive submission and concentration, all joining in unison in a repeated chant or hymn, our strong impression is likely to be that despite all the variations in culture and tradition that have shaped these differing sects and groups, there is in the end a single underlying religious impulse, perhaps as old as humanity itself, which is manifesting itself here. And as we watch the monks completing their meditation and liturgical observance and turning towards the more active part of their daily routine - which will almost certainly include acts of compassion towards others, or service to those in need or distress - we are likely to be struck again with the overlap between these different ways of life, rather than by the metaphysical doctrines that may divide them.

One could of course argue that the above similarities apply only to rather special groups of people - those who have chosen a monastic style of existence that sets them apart from the occupations and involvements of ordinary human life. But the broad category of spiritual praxis is certainly not confined to those with priestly or monastic vocations, nor indeed is it even necessarily restricted to those who would describe themselves as religious as witnessed in our own time by the apparently growing numbers who classify themselves as 'spiritual but not religious'. It is striking that this latter group includes many of the so-called 'new atheists', some of whom have underlined the importance in their lives of certain heightened forms of spiritual experience, the significance of which, they argue, does not depend in any way on theistic or other metaphysical beliefs. Thus Christopher Hitchens, towards the end of his life, declared in a debate: 'I'm a materialist ... yet there is something beyond the material, or not entirely consistent with it, what you could call the Numinous, the Transcendent ... It's in certain music, landscape, certain creative work, and without this we really would merely be primates. It's important to appreciate [this] and religion has done a very good job of enshrining it in music and architecture.' 11 Similarly, Sam Harris, another prominent spokesman for the new atheism, has observed that 'spiritual experiences often constitute the most important and transformative moments in a person's life. Not recognizing that such experiences are possible or important can make us appear less wise even than our craziest religious opponents.' 12

Once again, then, we seem to come up against the fact of convergence not at the theoretical or doxastic level (for what wider gulf in belief-systems could there be than that

\footnotetext{
${ }^{11}$ Christopher Hitchens, in debate with Tony Blair [2010], quoted in Jules Evans, 'The New Atheists are actually transcendentalists', http://philosophyforlife.org/the-new-atheists-are-actuallytranscendentalists/, posted 24 January 2014.

${ }^{12}$ Sam Harris, Waking Up: A Guide to Spirituality Without Religion (New York: Simon and Schuster, 2014), cited in Evans, 'The New Atheists.'
} 
which divides the theist from the typical secularist critic of religion?), but at the level of praxis and experience. Believers and non-believers alike may be moved to tears by the beauties of nature, or by a master-work such as Bach's Matthew Passion, or by those moments in our relations with others when we lay aside our demanding and egoistical selves and feel filled with outgoing impulses of tenderness and love. The labels used may be different - religious people may speak of 'sacred' moments, while humanist and atheists may, like Hitchens, prefer terms such as 'numinous', but the specially charged nature of the experiences themselves cannot be denied. They take us beyond the routine world of useful toil and pleasant recreation, important and valuable though those things are, towards a domain of value and meaning that is not obviously manifest in the material structures that compose our bodies and our environment, nor derived merely from our biologically inherited drives, but which seems to reflect something richer, deeper and more awe-inspiring. ${ }^{13}$

How are we to interpret these 'sacred' or 'numinous' experiences, which seem to be a part of our universal human birthright, and whose special resonance is likely to be acknowledged by anyone who 'wears a human heart', ${ }^{14}$ irrespective of religious allegiance or its lack? The very fact of their universality is, for those who hope for better things for mankind, encouraging. They are of a different order from our desire for progress in science or technology (urgently though we need the latter in order to address the dangers that threaten both our own species and perhaps all living forms on the planet), but relate instead to our need to transcend our nature, reaching beyond the given to something finer. This 'reaching forward' is not merely a matter of intellectual inquiry, but involves deep emotional and imaginative sensibility, together with what can only be described as moral yearnings, for selfimprovement and for deeper awareness of the demands and mysteries of love and compassion; and to this should be added 'aesthetic' yearnings (for want of a better term) impulses to struggle upwards and attune ourselves to what is beautiful, not just passively but also actively, by creating shapes, words, colours and sounds that resonate with our sensibilities and give expressions to our longings.

If there is indeed a convergence here at the level of lived human experience, there will of course nevertheless be wide differences in how religious and non-religious people respectively understand and interpret what is going on. For the theist, the very universality of spiritual impulses and experiences of the sacred may be adduced as evidence for a sensus divinitatis, ${ }^{15}$ a capacity to apprehend the divine that in some form or other is shared by all humankind, even though it may not necessarily be recognized under that description. The secularist, by contrast, is likely to favour a 'naturalistic' interpretation - perhaps that these impulses and experiences derive from biologically explicable capacities and dispositions inherited from our evolutionary past. It is not perhaps obvious how a capacity for so-called 'spiritual experience' might confer a selective advantage, but there is great deal of speculation in the contemporary literature on how religious and quasi-religious impulses might have played a useful role (e.g. in promoting social solidarity), or else been a by-product of other traits whose presence was beneficial in evolutionary terms. ${ }^{16}$ Except for the crudest reductionists, however, the question of the social and biological origins of these phenomena does not affect the question of their value and importance for us here and now; and that value

${ }^{13}$ See John Cottingham, How to Believe (London: Bloomsbury, 2015), Ch. 2, sectn 1.

14 The phrase is David Hume's, speaking of our universal moral impulses of benevolence, in his Enquiry concerning the Principles of Morals [1751], Section V, part 2.

15 'a tacit confession of a sense of deity inscribed in the hearts of all.' John Calvin, Institutes [Christianae religionis institutio, 1536], I, 3, 1 .

${ }^{16}$ See further Joseph A. Bulbulia, 'The Evolution of Religion', in The Oxford Handbook of Evolutionary Psychology, ed. R. Dunbar and L. Barret (Oxford: Oxford University Press, 2007), Ch. 44. 
and importance, as we have seen, is something on which religious and non-religious thinkers seem happy to agree, notwithstanding the radical divergence in their respective worldviews.

\section{Reconciliation and its limits}

Those who, like the present writer, are by nature reconciliationists, wanting to reach out to those of different belief systems in the hope of finding common ground, will no doubt welcome the signs of convergence at the level of human praxis and experience that have so far been sketched out. But it is important that our search for what is shared does not lead us to gloss over crucial differences, or to assimilate outlooks that are ultimately incommensurable. Convergence in behaviour is, notoriously, not an infallible indicator of 'what lies beneath', in the thoughts and feelings of the subjects in question. Three people might witness a public execution with identical composure and stillness of posture, yet the first be wracked with sympathy for the victim, the second be bursting with sadistic delight at the demise of his enemy, while the third is simply blankly indifferent. And even were it to be the case, as some devotees of so-called 'neurophilosophy'17 suppose, that we could 'read off' the mental states of the subjects from a scan of their brain activity, so that we could tell whether the attitudes were ones of distress or exultation or neutrality, there may still be significant divergences in how each of the three subjects interprets the meaning of what is going on - divergences which could not be identified even through the most exhaustive printout of the respective bodily states, including the electro-chemistry of the brain.

The reason for this limitation in what scientific investigation could even in principle establish is, to put it crudely, that 'meanings ain't in the head', as the American philosopher Hilary Putnam once trenchantly observed, ' 18 To understand the meaning of what someone is thinking about and experiencing we need to look not just at the physically investigable processes going on inside the body, brain and nervous system, but outwards, to the complex social network of human interaction that generates all our conceptual resources and allows us to describe and interpret our experience.

Reflecting on the implications of this should raise serious doubts about the claim that there is one single phenomenon, called 'spiritual experience', or 'experience of the sacred or the numinous' that is common currency irrespective of the religious, or non-religious, outlooks of the practitioners. So although a reconciliationist may initially be hospitable to the idea that one can cultivate spiritual awareness without religion, and in particular without theistic religion, we need to pause and ask exactly what kind of awareness is in question. It is certainly a welcome development to find secularists such as Sam Harris paying attention to the phenomenon of spiritual experience (the 'great hole in secularism, humanism, rationalism, atheism ...'), ${ }^{19}$ and acknowledging that there is more to understanding reality than many scientistically oriented philosophers are commonly prepared to allow. But spiritual experience cannot be considered in isolation, as a kind of 'self-standing' phenomenon, as it were. We always need to ask about what the experience is an experience of. And it is significant that the reality that is disclosed by spiritual experience according to naturalists such as Harris (who in this area is strongly influenced by Buddhism and kindred creeds)

\footnotetext{
${ }^{17}$ For this term, see for example Patricia S. Churchland, Neurophilosophy: Towards a Unified Science of the Mind-Brain (Cambridge, Mass.: MIT Press, 1989).

${ }^{18}$ Hilary Putnam, 'The Meaning of Meaning' [1975], in Philosophical Papers, Vol. 2 (Cambridge:

Cambridge University Press, 1985).

${ }^{19}$ Harris, Waking Up, p. 202.
} 
turns out to be a wholly impersonal one. It is not one that addresses us personally with a call to change, or requires anything of us, but is a blank and impersonal flux. ${ }^{20}$

This is not to deny that the spiritual mindfulness that growing numbers of contemporary secularists advocate may be cultivated in ways that do not require subscribing to any of the theistic doctrines that they deplore. And many of the resulting states mentioned by Harris, and familiar from many types of Eastern religion, turn out to have very considerable appeal: a sense of 'selfless wellbeing', 'self-transcendence', 'paying attention to the present moment', a feeling of 'boundless love' (albeit of a fundamentally impersonal kind), a sense of being 'at one with the cosmos', and 'bringing stress to an end'. ${ }^{21}$ Nothing said in the present essay is intended to deny the value of such goals. But we need to recognize how far they diverge from the religious encounters with the sacred described in many of the texts of classical theism - those intensely personal encounters, infused with awe and charged with moral significance, where the individual feels him or herself to be checked, to be scrutinized, and to be called upon to respond and to change.

This electrifying charge of moral significance is vividly apparent in many much admired passages in the Hebrew Bible, that most seminal source for classical Western theism, as in the following Psalm:

Let the heavens be glad, and let the earth rejoice: let the sea roar, and all it contains. Let the field exult, and all that is in it: then all the trees of the forest will sing for joy Before the LORD, for he comes, he comes to judge the earth: he will judge the world in righteousness, and the peoples in his faithfulness. ${ }^{22}$

The language of such texts may be uncongenial to contemporary scientific naturalists, who pride themselves on having totally rejected the notion of any supernatural being (the 'God hypothesis', as Richard Dawkins disparagingly calls it). ${ }^{23}$ But reading such passages in context makes it clear that God is not introduced as an immaterial force that is supposed to explain the behaviour of the oceans and fields and the woods; rather the vivid beauty and splendour of the natural world is that which makes manifest the divine. The world is understood religiously - not as a blank impersonal process, not as A. E. Housman's 'heartless witless nature', ${ }^{24}$ not as a manifestation of 'blind, pitiless indifference', as Richard Dawkins characterizes it, ${ }^{25}$ but as 'charged with the grandeur of God'. This is the vision powerfully expressed by Gerard Manley Hopkins when he speaks of all things as being 'charged with love ... charged with God, [so that] if we know how to touch them [they] give off sparks and take fire, yield drops and flow, ring and tell of him.' 26

The feebleness of modern labels like 'aesthetic' for the type of language found in the Psalm just quoted is even more apparent in an earlier Psalm, where God is described as the one who 'breaks the cedars of Lebanon and makes Lebanon skip like a calf', who 'shakes the

\footnotetext{
20 The argument of the next few paragraphs draws on material from Ch. 5 of Cottingham, How to Believe.

${ }^{21}$ Harris, Waking Up, pp. 17, 18, 3, 5, 43, 48.

22 Psalms 96 [95]: 11-13.

${ }^{23}$ Richard Dawkins, The God Delusion (London: Bantam Press, 2006), Ch. 2.

${ }^{24}$ In 'Tell me not here, it needs not saying', Last Poems (1922).

${ }^{25}$ Richard Dawkins, Rivers Out of Eden (New York: Basic Books, 1995), p. 133.

26 G. M. Hopkins, Note-books and Papers, ed. H. House (Oxford: Oxford University Press, 1937), p. 342; cited in W. H. Gardner (ed.), The Poems and Prose of Gerard Manley Hopkins (Harmondsworth: Penguin, 1953), p. 231. Compare Hopkins's famous poem, which begins 'The world is charged with the grandeur of God', from Poems (1876-1889).
} 
wilderness and strips the forests bare, while all in the temple cry "Glory"'. ${ }^{27}$ The cry of 'Glory' (in Hebrew kavod כָּבֹ ) signifies something weighty with significance, sacred, mysterious, a manifestation of the divine, as conveyed in the description of the pillar of fire and cloud which led the Israelites out of Egypt, or the cloud atop Mount Sinai where God's law was manifest to Moses. ${ }^{28}$ We are not talking of 'natural beauty' in the attenuated modern sense, but of something fearful that calls forth reverence and awe, like the burning bush, flaming but never consumed, where Moses was told to keep his distance. ${ }^{29}$ These are not 'impressive sights', of the kind familiar from television nature programmes, but events pregnant with moral significance, as is clear from the lines in the earlier Psalm quoted, where the forests 'sing for joy' not just in pantheistic exuberance, as it were, but rather because the world is to be judged. In psychological or phenomenological terms, what is happening here is an experience where the subject is overwhelmed by the power and beauty of nature in a way that is somehow intertwined with awareness of one's own weakness and imperfection, and a sense of confrontation with the inexorable demands of justice and righteousness. The 'religious understanding' involved here is, in short, the kind of awareness which enables one to see the world transfigured, so that it is irradiated with meaning and value, and the human subject, caught up in that mystery, is unmistakeably called on to be no longer a spectator, a mere 'tourist', but to respond, to be a morally responsive agent, part of a cosmos that is diaphanous, transparent to the divine.

Set against this, the meditative goals of impersonal and boundless oceanic wellbeing have an essentially quietist character. They stem from a long Eastern tradition of spirituality in which the paramount objective is achieving bliss by detaching oneself from the stressful world of struggle, commitment and dependency. It is of course true that many Eastern sages advocate a path of virtue and right conduct (and indeed the compassionate outlook of many practitioners of Eastern spirituality is greatly to be respected and admired); so in this sense there is an ethical component involved. But it is not a component that is intrinsically connected to any underlying vision of moral goodness at the heart of reality; for the Eastern vision is one in which personal commitments and demands are based on an illusion, and ultimate reality is simply an impersonal continuum of conditions that arise and pass away.

Although constraints of space require us to bring to a close this brief survey of the content of spiritual experience across the theistic, non-theistic and secularist outlooks, enough has perhaps been said to indicate that the initially promising idea of convergence at the level of spiritual praxis and experience is not in all respects well founded. For the reconciliationist, concerned about the evident dangers of religious confrontation in today's world, this is no doubt a disappointing result. But if the frameworks and worldviews we have been discussing turn out in the end to be radically and irreconcilably distinct, it does not follow that this need necessarily lead to an angry standoff between those of different outlooks. The religious bigotry and oppression that blighted our history in past centuries has largely faded in much of the developed world (though significant swathes of fundamentalist intolerance still remain even in supposedly 'advanced' Western countries, not to mention other parts of the world). But when all that is said, it cannot be denied that we find at the heart of the theistic vision at its best, together with the secular liberalism and humanism that are its offspring, and also running through much Eastern religious thought, a precious thread of compassion and respect for our fellow human beings, which no divergences of doctrine and belief, however radical, ought to undermine.

\footnotetext{
27 Psalm 29 [28]: 5-9.

${ }^{28}$ Exodus $13: 21 ; 16: 10 ; 24: 16$.

${ }^{29}$ Exodus 3:5.
} 